\title{
PENGEMBANGAN PRODUK OLAHAN TEPUNG SAYURAN DI DESA SINDON KECAMATAN NGEMPLAK KABUPATEN BOYOLALI
}

\author{
Muhtadi ${ }^{1}$ Rusdin Rauf ${ }^{2}$, Kun Harismah ${ }^{3}$, dan Saifuddin ${ }^{4}$ \\ ${ }^{1}$ Fakultas Farmasi \\ ${ }^{2}$ Prodi Gizi - Fakultas Ilmu Kesehatan, \\ ${ }^{3}$ Prodi Teknik Kimia - Fakultas Teknik, \\ ${ }^{4}$ Fakultas Agama Islam \\ Universitas Muhammadiyah Surakarta \\ Jl. A. Yani Tromol Pos I, Pabelan, Kartasura, Surakarta 57102 \\ Email : muhtadi@ums.ac.id
}

\begin{abstract}
In the Pemitra community service activities for Product Development Processed Vegetables in Desa Sindon, Ngemplak Boyolali, has been done by training, and assistance to the women of PKK, Aisyah and "Mawar" farmers group in Desa Sindon to improve the understanding, skills and marketing development products processed from starchy vegetables. In this Pemitra had conducted training activities to product of starchy vegetables, then trained the skill of making a wet noodle, instant noodles, crackers and biscuits from flour processed vegetables. The results that have been obtained from this Pemitra activities all women partners group have been able to get the skills to cultivate vegetable flour into wet noodles, instant noodles, crackers and biscuits. However, constraints and problems still faced was to start a business production and developing marketing of products processed starchy vegetables group of women who fostered still very low, so the follow-up to the next community services activities will be focused on to accompany the women group of PKK, Aisyah and farmers "Mawar" in terms of development, production, packaging, licensing P-IRT and marketing of products from starchy vegetables.
\end{abstract}

Kata Kunci : produk olahan tepung sayuran, desa Sindon, Ngemplak, Boyolali

\section{PENDAHULUAN}

Kabupaten Boyolali memiliki luas wilayah lebih kurang 101.510.0965 ha atau kurang 4,5\% dari luas Propinsi Jawa Tengah. Wilayah Boyolali terletak antara $110^{\circ} 22^{\prime} \mathrm{BT}$ - 110 50' BT dan 7³6' LS - 771'LS dengan ketinggian antara 100 meter sampai dengan 1.500 meter dari permukaan laut.

1. Sebelah timur dan selatan merupakan daerah rendah, sedang sebelah utara dan barat merupakan daerah pegunungan. Sebelah utara : Berbatasan dengan wilayah Kabupaten Semarang dan Kabupaten Grobogan.

2. Sebelah Timur : Berbatasan dengan wilayah Kabupaten Sragen, Kabupaten Karanganyar, Kota Surakarta dan Kabupaten Sukoharjo.

3. Sebelah Selatan : Berbatasan dengan wilayah Kabupaten Klaten dan DIY.

4. Sebelah Barat : Berbatasan dengan wilayah Kabupaten Magelang dan Kabupaten Semarang. 
Kabupaten Boyolali merupakan salah satu daerah sentra pertanian di Jawa Tengah, dengan komoditi unggulan seperti jagung, ketela, nanas, pisang, papaya, ubi jalar, ubi kayu dan aneka sayuran. Kabupaten Boyolali memiliki 19 kecamatan, salah satunya adalah kecamatan Ngemplak yang terletak di sebelah timur dari wilayah kabupaten Boyolali dan lebih dekat dengan wilayah kota Surakarta dan kabupaten Karanganyar. Kecamatan Ngemplak merupakan daerah yang sangat istimewa bagi kabupaten Boyolali karena memiliki fasilitas yang sangat penting, yaitu adanya bandara internasional Adi Soemarmo dan embarkasi haji Donohudan, terletak di wilayah kecamatan Ngemplak.

Kecamatan Ngemplak secara administratif memiliki 12 desa salah satunya adalah desa Sindon, yang terletak persis di sebelah utara bandara Adi Soemarmo. Sebagian besar warganya adalah petani sayuran kangkung, bayam dan sawi, disamping sebagian besar juga petani padi. Jumlah penduduk desa Sindon \pm 6.500 jiwa dimana lebih dari separuhnya berprofresi sebagai petani. Sebagian petani menggarap tanah milik Bandara Adi Soemarmo/TNI AU dengan system sewa atau bagi hasil. Luas areal lahan milik Bandara Adi Soemarmo yang digunakan dan dimanfaatkan oleh petani desa Sindon lebih dari 50 hektar, dengan ditanami padi, dan sayur-sayuran seperti kangkung, bayam dan sawi. Produksi sayuran dari desa Sindon cukup melimpah apalagi pada saat musim hujan, tidak kurang dari 5 ton/hari dihasilkan, sehingga harga sayuran seringkali jatuh pada saat produksi yang melimpah ini. Harga normal seikat kangkung dari petani adalah Rp. 400,- s.d 500,-/per-ikat, dan menjadi Rp. 200,- disaat produksi melimpah. Seringkali petani merasa frustasi dan tanaman dibiarkan saja tidak dipanen. Pengetahuan petani untuk mengenali perilaku pasar sayuran masih sangat terbatas, sehingga petani sangat bergantung pada pedagang atau pengepul yang ada di desa Sindon. Ketrampilan untuk mengembangkan produk sayuran menjadi produk-produk olahan yang memiliki masa simpan lebih lama, bernilai ekonomis dan memiliki kualitas serta khasiat sebagai makanan suplemen belum diketahui oleh masyarakat petani desa Sindon, padahal bahan-bahan sayuran merupakan sumber protein nabati dan serat yang bermanfaat bagi metabolism tubuh. Oleh karena itu pengenalan, pelatihan dan pendampingan produk olahan sayuran menjadi keripik, biscuit dan mie dari bahan tepung sayuran sangat menarik untuk diajarkan dan dilatihkan bagi warga desa Sindon.

Produksi sayuran dari pertanian di desa Sindon cukup besar yakni 2 ton s.d 5 ton/hari, tergantung pada cuaca dan ketersediaan air. Pada saat musim penghujan, seringkali harga sayuran jatuh hingga nilai jual terendah, sehingga banyak petani yang tidak merawat tanamannya dengan baik. Padahal sayuran ini dapat dikembangkan menjadi produk olahan yang bernilai ekonomis dan meningkatkan harga jual sayuran. Persoalan ini perlu penyadaran, peningkatan pemahaman dan pendampingan ketrampilan bagi petani, ibu-ibu jamaah pengajian Aisyah, ibu-ibu kelompok wanita tani, dan ibu-ibu PKK di desa Sindon, sebagai kelompok sasaran antara dalam kegiatan pemberdayaan masyarakat.

Secara umum, permasalahan yang dihadapi masyarakat di desa Sindon untuk meningkatkan konsumsi dan nilai ekonomi dari sayuran adalah:

1. Masyarakat belum memiliki keterampilan dalam pembuatan tepung sayuran dengan mutu yang baik.

2. Masyarakat belum memiliki peralatan untuk membuat tepung sayuran.

3. Masyarakat belum memahami cara mengolah produk pangan berbahan tepung sayuran seperti mie basah, mie instan, kerupuk, peyek dan biskuit. 
4. Masyarakat belum memahami bagaimana cara memasarkan produk pangan olahan dari sayuran.

Beberapa tahun terakhir, terjadi peningkatan kasus penyakit degeneratif terkait pola makan yang tidak seimbang. Pola konsumsi pangan masyarakat Indonesia cenderung lebih banyak mengkonsumsi sumber karbohidrat terutama beras. Disisi lain sumber zat gizi mikro berupa mineral masih cukup rendah. Demikian pula dengan konsumsi sumber serat pangan yang dikategorikan sebagai pangan fungsional, masih belum mencukupi anjuran untuk hidup sehat. Penelitian yang telah dilakukan oleh mahasiswa Gizi UMS pada tahun 2014 terhadap anak remaja sekolah bahwa $100 \%$ responden menunjukkan tingkat konsumsi serat yang masih kurang dari anjuran. Kondisi ini sangat ironi karena Indonesia memiliki potensi pangan sumber zat gizi mikro dan serat yang cukup baik yaitu sayuran. Dengan kondisi lahan pertanian yang subur serta iklim dengan sinar matahari yang cukup, upaya budidaya sayuran di Indonesia dapat berhasil dengan baik (Koswara, 2009; Santosa, 2011; Duncan, et. al., 2012).

Upaya yang dapat dilakukan untuk memenuhi kebutuhan zat gizi seimbang adalah melalui diversifikasi pangan atau penganekaragaman pangan. Tidak ada satu jenis bahan pangan yang memenuhi semua zat gizi yang diperlukan tubuh, sehingga pemenuhannya dari beragam sumber pangan. Penganekaragaman pangan terdiri atas dua tipe yaitu penganekaragaman secara horisontal dan secara vertikal. Penganekaragaman pangan secara horisontal dilakukan melalui penganekaragaman sumber pangan, baik sumber karbohidrat, protein, lemak, vitamin dan mineral. Sedangkan penganekaragaman vertikal terkait dengan penganekaragaman hasil olahan (Koswara, 2009).
Pemerintah kabupaten Boyolali telah memberikan bantuan berupa pembinaan teknis serta bibit beberapa tanaman produktif, termasuk sayuran kepada kelompok wanita tani di desa Sindon kecamatan Ngemplak. Pembinaan teknis diberikan terkait dengan pemanfaatan pekarangan sebagai salah satu cara untuk meningkatkan keanekargaman pangan. Namun demikian upaya tersebut belum dapat memberikan hasil yang optimal karena tingkat konsumsi sayuran masyarakat Indonesia masih cukup rendah. Untuk mempercepat keberhasilan program penganekaragaman pangan, maka penganekaragaman horisontal dan vertikal perlu dilakukan secara beriringan.

Upaya diversifikasi sayuran secara vertikal dengan penganekaragaman hasil olahannya, tidak hanya dapat meningkatkan konsumsi sayuran, tetapi juga dapat menjadi nilai tambah ekonomi masyarakat. Sayuran, oleh masyarakat dijual dalam bentuk segar, namun harga jual maupun volume penjualannya terhitung masih cukup kecil. Disisi lain sayuran merupakan bahan pangan yang mudah mengalami kerusakan setelah dipanen. Jika tidak segera diolah, maka kerusakan sayuran dalam jumlah melimpah menjadi kerugian yang cukup besar bagi masyarakat (Rusmana dan Saefulhadjar, 2007).

Sayuran dapat diperpanjang masa simpannya dengan cara diolah menjadi tepung sayuran. Pengolahan tepung sayuran dapat dilakukan dengan menggunakan teknologi sederhana yang dengan mudah dapat dilakukan oleh masyarakat. Dalam bentuk tepung, selain lebih mudah dalam proses pendistribusian dan perdagangan, tepung sayuran juga menjadi produk antara yang sangat fleksibel untuk diolah menjadi beragam produk pangan yang digemari masyarakat khususnya remaja, seperti mie instant, mie basah, kerupuk, peyek dan biskuit. Dalam bentuk olahan, produk 
berbahan sayuran akan digemari oleh berbagai lapisan masyarakat termasuk anakanak dan remaja karena disamping penampilan dan citarasanya yang menarik, produk tersebut juga lebih menyehatkan dibanding produk lainnya yang telah beredar di pasaran (Slamet, 2011; Syahza, 2003).

Tujuan dan manfaat dari kegiatan pengabdian masyarakat ini adalah:

1. Masyarakat menguasai teknik pembuatan tepung sayur, yaitu kangkung, bayam dan sawi.

2. Masyarakat memahami cara menggunakan beberapa peralatan dalam pembuatan tepung sayuran.

3. Masyarakat dapat mengolah berbagai produk pangan berbahan tepung sayuran, seperti mie basah, mie instan, kerupuk, peyek kacang, dan biskuit.

4. Masyarakat memiliki ide untuk mengembangkan produk olahan tepung sayuran menjadi ketrampilan untuk pengembangan usaha pertanian sayuran.

\section{METODE PELAKSANAAN}

Pelaksanaan kegiatan pengabdian Pemitra di desa Sindon kecamatan Ngemplak kabupaten Boyolali ini, tim pelaksana membagi kegiatan dalam hal pelatihan dan pembimbingan terhadap ibu-ibu PKK, Aisyah, dan kelompok wanita tani di desa Sindon kecamatan Ngemplak Boyolali menjadi beberapa tahapan, sebagai berikut: Tahap I. Audensi ke pemerintah desa, pimpinan cabang Muhammadiyah, pimpinan ranting Muhammadiyah, pimpinan ranting Aisyah, kelompok PKK dan wanita tani desa Sindon tentang potensi dan pemanfaatan sayuran yang banyak dihasilkan oleh warga desa Sindon.

Tahap II. Persiapan dan koordinasi pelatihan pembuatan tepung sayuran.
Tahap III. Tahap pelatihan pembuatan tepung sayuran, produk olahan tepung sayuran yaitu mie basah dan mie kering,

Tahap IV. Tahap pelatihan dan pembuatan produk olahan sayuran berupa biskuit dan kerupuk dari tepung sayuran.

Tahap V. Tahap pendampingan dan monitoring pengembangan ketrampilan produksi olahan sayuran.Tahap VI. Tahap evaluasi pelaksanaan kegiatan pemitra secara keseluruhan di desa Sindon Ngemplak Boyolali.

\section{HASIL DAN PEMBAHASAN}

Pelaksanaan program Pemitra bagi pengembangan produk olahan tepung sayuran di desa Sindon kecamatan Ngemplak kabupaten Boyolali dengan tujuan utama untuk meningkatkan kreatitifitas, diversifikasi dan pendapatan petani sayuran di desa Sindon melalui pemanfatan dan produksi produk-produk olahan dari tepung sayuran. Hasil pelaksanaan kegiatan pemitra di desa Sindon telah dilakukan introduksi pengetahuan dan ketrampilan untuk pembuatan tepung sayuran (kangkung, bayam dan sawi) yang banyak dan melimpah di desa Sindon untuk dikembangkan menjadi produk olahan tepung sayuran seperti mie basah, mie instant, kerupuk, dan biskuit.

Pemanfaatan sayuran menjadi tepung sayuran, untuk diolah menjadi produk olahan tepung sayuran dilator belakangi kondisi obyektif dan kajian secara teoritis, tentang fenomena peningkatan kasus penyakit degeneratif terkait dengan kualitas makanan yang dikonsumsi dengan kandungan gizi yang tidak seimbang, yaitu tinggi lemak/minyak, tinggi karbohidrat, tinggi garam, dan rendah serat. Dampak yang terjadi dengan makanan dengan gizi yang tidak seimbang, untuk jangka panjang adalah munculnya penyakit degenerative 
seperti diabetes, penyakit kardiovaskuler seperti jantung dan hipertensi, serta kanker kolon, usus, dll.

Padahal sebenarnya masyarakat memiliki banyak potensi untuk mencukupi kebutuhan makanan dengan kandungan gizi yang seimbang, yang dapat didayagunakan untuk mencegah terjadinya penyakitpenyakit degenerative tersebut. Namun karena pengetahuan dan produktivitas masyarakat yang masih rendah, maka potensi tersebut belum dimanfaatkan secara optimal. Padahal secara teoritis, sayuran merupakan makanan dengan sumber vitamin dan mineral yang sangat diperlukan oleh tubuh manusia.

Desa Sindon dengan kemampuan produksi sayuran tiap harinya yang lebih dari $500 \mathrm{~kg}$ sayuran, baik berupa sayuran kangkung, bayam dan sawi baik jenis lokal maupun sawi Jepang, tentunya memiliki potensi ekonomi dan kemampuan supply bahan sayuran dengan kualitas gizi yang sangat baik. Namun, karena tingkat pengetahuan yang rendah dan belum adanya sosialisasi tentang manfaat dan potensi yang dapat dikembangkan dari hasil panen sayuran menjadi produk olahan tepung sayuran optimalisasi produk hasil pertanian sayuran belum berkembang.

Kendala yang seringkali muncul dalam pertanian sayuran adalah harga produk panen yang relative murah, harga jatuh di saat masa panen raya atau musim hujan, masa simpan produk yang sangat singkat, dan budaya masyarakat, khususnya anak-anak yang tidak gemar makan sayuran. Ini semua yang menyebabkan harga hasil panen pertanian sayuran kurang ekonomis dan kompetitif. Oleh karena itu, pemikiran dan ketrampilan untuk memanfaatkan sayuran menjadi produk-produk olahan yang bernilai secara ekonomis, higienis dan kualitas gizi yang tinggi dan berimbang, sangat penting untuk dilatihkan kepada masyarakat, khususnya petani dan keluarga petani sayuran di desa Sindon.
Pada kegiatan pemitra di desa Sindon ini telah dilakukan pelatihan dan pendampingan bagi ibu-ibu PKK, pengajian Aisyah, dan kelompok wanita tani yang meliputi :

1. Pelatihan pembuatan tepung sayuran dari kangkung, bayam dan sawi (lokal dan Jepang). Pembuatan tepung sayuran bertujuan untuk meningkatkan masa simpan sayuran, menjaga kualitas gizi dan meningkatkan potensi diversifikasinya menjadi produk-produk olahan berbasis tepung sayuran.

2. Pelatihan dan pendampingan pembuatan mie basah dan mie kering (instan) dengan memanfaatkan tepung sayuran. Hal ini bertujuan untuk meningkatkan kualitas mie yang dibuat dan meningkatkan penerimaan produk mie olahan bagi konsumen anak-anak.

3. Pelatihan dan pendampingan pembuatan kerupuk dan biskuit. Kelompok ibu-ibu (PKK, Aisyah, dan kelompok wanita tani) menjadi lebih mengetahui diversifikasi produk olahan tepung sayuran.

Pemilihan mitra yang lebih difokuskan kepada ibu-ibu (PKK, Aisyah, dan kelompok wanita tani) karena kelompok ini yang seringkali bergelut dengan hasil panen sayuran, memiliki waktu yang relative panjang dan luwes, telaten dan secara umum suka dengan ketrampilan memasak makanan.

Keuntungan yang telah diperoleh oleh mitra (ibu-ibu PKK, Aisyah dan kelompok wanita tani) adalah :

1. Peningkatan pengetahuan dan ketrampilan mengolah sayuran menjadi tepung sayuran yang dapat dikembangkan menjadi produk-produk olahan tepung sayuran sesuai dengan ketrampilan dan kreatifitas ibu-ibu.

2. Peningkatan pengetahuan dan ketrampilan untuk memproduksi mie basah, mie kering, kerupuk dan biskuit dari tepung sayuran. 
3. Tumbuhnya semangat kebersamaan untuk memulai usaha/bisnis dari produk olahan tepung sayuran. Berikut tabel yang menjelaskan kondisi masyarakat desa Sindon sebelum dan sesudah pelaksanaan pemitra pengembangan produk olahan tepung sayuran di desa Sindon, Ngemplak, Boyolali. Sesuai tabel 1:

Tabel 1.

Kondisi sebelum dan sesudah pelaksanaan kegiatan Pemitra di desa Sindon, Ngemplak, Boyolali

\begin{tabular}{|c|c|c|}
\hline Uraian & $\begin{array}{c}\text { Kondisi sebelum kegiatan } \\
\text { pemitra }\end{array}$ & $\begin{array}{c}\text { Kondisi sesudah pelaksanaan } \\
\text { Pemitra }\end{array}$ \\
\hline $\begin{array}{l}\text { Pengolahan pasca panen } \\
\text { sayuran }\end{array}$ & $\begin{array}{l}\text { Sayuran dijual dalam bentuk } \\
\text { mentah (per-ikat) }\end{array}$ & $\begin{array}{l}\text { Sebagian sayuran diolah menjadi } \\
\text { tepung sayuran, khususnya } \\
\text { kangkung dan sawi Jepang }\end{array}$ \\
\hline $\begin{array}{l}\text { Ketrampilan pengolahan } \\
\text { produk sayuran }\end{array}$ & $\begin{array}{l}\text { Masyarakat hanya mengolah } \\
\text { sayuran menjadi sayur mayur } \\
\text { konvensional }\end{array}$ & $\begin{array}{l}\text { Masyarakat memiliki ketrampilan, } \\
\text { kreatifitas dan diversifikasi produk } \\
\text { olahan tepung sayuran seperti mie, } \\
\text { kerupuk dan biscuit. }\end{array}$ \\
\hline $\begin{array}{l}\text { Peningkatan nilai ekonomi } \\
\text { sayuran }\end{array}$ & $\begin{array}{l}\text { Masyarakat hanya menjual } \\
\text { sayuran dengan nilai yang } \\
\text { relative murah ( } \pm \text { Rp 500/ikat) }\end{array}$ & $\begin{array}{l}\text { Masyarakat telah diberi } \\
\text { pengetahuan dan ketrampilan } \\
\text { untuk meningkatkan nilai eknomis } \\
\text { produk olahan tepung sayuran. }\end{array}$ \\
\hline pengembangan & $\begin{array}{lr}\text { Masyarakat } & \text { belum } \\
\text { mengetahui } & \text { potensi } \\
\text { peningkatan } & \text { dan } \\
\text { pengembangan } & \text { ekonomi dari } \\
\text { produk sayuran } & \end{array}$ & $\begin{array}{l}\text { Masyarakat lebih terbuka } \\
\text { wawasannya untuk pengembangan } \\
\text { potensi ekonomi dari produk } \\
\text { olahan sayuran. }\end{array}$ \\
\hline
\end{tabular}

Pelaksanaan pemitra di desa Sindon ini tentunya menemui kendala dan hambatan, yakni :

1. Semangat untuk memulai dan mengembangkan usaha berbasis produk olahan dari tepung sayuran ini masih sangat minim, masyarakat butuh contoh konkret keberhasilan mengelola usaha.

2. Keterbatasan modal usaha dan teknologi produksi untuk pengembangan usaha produk olahan tepung ini, masih menjadi alasan bagi ibu-ibu PKK, Aisyah, kelompok wanita tani dalam memulai dan mengembangkan usaha.

Catatan evaluasi terhadap kendala dan hambatan ini, tentu menjadi hal yang sangat berharga pada tindak lanjut pelaksanaan pengabdian di desa Sindon.

\section{SIMPULAN DAN SARAN}

\section{Simpulan}

Dari kegiatan Pemitra pengembangan produk olahan sayuran di desa Sindon kecamatan Ngemplak kabupaten Boyolali telah diperoleh hasil sebagai berikut :

a. Peningkatan pengetahuan dan ketrampilan melalui kegiatan diklat dan pendampingan untuk pembuatan tepung dari sayuran, dan produk olahan mie basah dan mie kering instant bagi ibuibu PKK, pengajian Aisyah, dan kelompok wanita tani desa Sindon.

b. Peningkatan pengetahuan dan ketrampilan diversifikasi produk olahan tepung sayuran melalui kegiatan diklat dan pendampingan untuk pembuatan kerupuk dan biskuit dari tepung sayur kangkung dan sawi Jepang. 
c. Tumbuhnya semangat kebersamaan dan keberlanjutan program dengan melibatkan pemerintah desa, dinas terkait dan pihak-pihak swasta yang ada di desa Sindon sangat membantu pengembangan usaha berbasis produk olahan sayuran dan potensi ekonomi lokal di desa Sindon.

\section{Saran}

Berdasarkan pembahasan dan kesimpulan di atas, kami mengemukaan beberapa saran, antara lain :

a. Kendala yang berupa semangat untuk mengawali wirausaha masih sangat rendah, sehingga masyarakat perlu diberi motivasi dan contoh sukses untuk pengembangan usaha berbasis produk tepung sayuran. b. Perlu ada dukungan untuk program lanjutan, untuk meningkatkan semangat, ketrampilan dan kemampuan pemasaran dari para ibu-ibu anggota PKK, pengajian Aisyah dan kelompok wanita tani desa Sindon.

\section{Persantunan}

Ucapan terimakasih disampaikan kepada :

1. Lembaga Penelitian dan Pengabdian kepada Masyarakat (LPPM) Universitas Muhammadiyah Surakarta yang telah memberikan dukungan moril dan finansiil dalam pelaksanaan Pemitra Desa Sindon ini.

2. Bapak Kepala Desa Sindon, kelompok wanita tani Mawar, ibu-ibu PKK dan Aisyah ranting Desa Sindon.

\section{DAFTAR PUSTAKA}

Duncan, K., Chompoothong, N., dan Burnette, R., (2012), Produksi Sayuran di Sepanjang Musim Hujan, ECHO Asia Notes, A Regional Supplement to ECHO Development Notes Issue 13, April 2012, http://c.ymcdn.com/sites/ members.echocommunity.org/resource/collection/2ADC04E9-EE7C-48C0-8DC9$\underline{826 B 93145277 /}$ 13 Produksi Sayuran di Sepanjang Musim Hujan FN2 Tyas \%281\%29.pdf diakses pada 4 Maret 2015

Koswara, S., (2009), Teknologi Pengolahan Sayuran dan Buah-Buahan (Teori Dan Praktek), eBookPangan.com,http://tekpan.unimus.ac.id/wp-content/uploads/2013/ 07/Teknologi-Pengolahan-Sayuran-dan-Buah-buahan-Teori-dan-Praktek.pdf diakses pada 2 Maret 2015.

Rusmana, D., Saefulhadjar, D., (2007), Pengaruh Pengolahan Limbah Sayuran Secara Mekanis Terhadap Kecernaan dan Efisiensi Penggunaan Protein pada Ayam Kampung Super, Penelitian Peneliti Muda, Tidak Dipublikasikan, Universitas Padjajaran Bandung.

Santoso, A., (2011), Serat Pangan (Dietary Fiber) Dan Manfaatnya Bagi Kesehatan, Magistra, No. 75 Th. XXIII Maret 2011, 35-40.

Slamet, A., (2011), Fortifikasi Tepung Wortel dalam Pembuatan Bubur Instan, AGROINTEK Vol 5, No. 1 Maret 2011, 1-8.

Syahza, A., (2003), Peluang Pengembangan Agribisnis Sayur-Sayuran di Kabupaten Karimun Riau, Jurnal SAGU, Vol. 2 No. 3, 27-33. 